\title{
Restriction on Malay Traditional Food Practices
}

\author{
Mohd Shazali Md. Sharif a, Mohd Salehuddin Mohd Zaharia, \\ Norazmir Md Nor ${ }^{b}$, Rosmaliza Muhammad ${ }^{a}$ \\ a Faculty of Hotel \& Tourism Management \\ b Faculty of Health Sciences \\ Universiti Teknologi MARA (UiTM), Puncak Alam, \\ 42300 Selangor, Malaysia \\ shazali@salam.uitm.edu.my
}

\begin{abstract}
This study attempted to recognize factors restrict young generations to practice Malay traditional festive foods. The study employs the observation method to tap into the actual food preparation process of the Malay festive celebration. Limited knowledge and skills of Malay traditional food and lack of family support the factors that identified to restrict young generation to practice Malay traditional festive foods.
\end{abstract}

Keywords: Malay traditional food; Malay young generation; food practices; preserving food knowledge

eISSN: 2398-4279 @ 2016. The Authors. Published for AMER ABRA by e-International Publishing House, Ltd., UK.. This is an open access article under the CC BY-NC-ND license (http://creativecommons.org/licenses/by-nc-nd/4.0/). Peer-review under responsibility of AMER (Association of Malaysian Environment-Behaviour Researchers), ABRA (Association of Behavioural Researchers on Asians) and cE-Bs (Centre for Environment-Behaviour Studies), Faculty of Architecture, Planning \& Surveying, Universiti Teknologi MARA, Malaysia.

https://doi.org/10.21834/ajqol.v1i1.31 


\subsection{Introduction}

Malaysia is a country that is rich in culture and tradition. Malay, Indian and Chinese as the main races in Malaysia, added with the Bumiputera of Sabah and Sarawak are several example races and ethnicities that are living in Malaysia. Each of these races has their celebrations and festivals. For example, the Indian celebrates Deepavali and Thaipusam while the Chinese celebrate Chinese New Year and Wesak Day. On the other hand, the Malay celebrates Islamic festivals such as Hari Raya Eidul Fitri and Hari Raya Eidul Adha. Each of the celebration is unique to each race and ethnicities and is continued by generation to a generation and has become a tradition to each ethnic thus, contributes to the uniqueness of Malaysia as a multiraces country in the eyes of the world. The ethnic or religion's celebration is incomplete if it had not served with traditional foods that have been practiced by generation to generations. Therefore, the continuity of traditional food should be nurtured or applied through knowledge transmission.

Transmission of traditional food knowledge is crucial to ensure continuity of practicing the traditional food among young generation (Mohd. Salehuddin, Mohd. Syaquif, Mohd. Zain, \& Langgat, 2011). If young generations refuse the learn, practice and transmit their traditional ethnic food culture and tradition, it will lead to the loss of the existence of the ethnic traditional food knowledge which has been practiced for generations (Md. Nor et al., 2012). Food knowledge transmission is the process by which knowledge or skill of cooking that has become a family tradition passed down or shared with family members and friends (Kwik, 2008). To ensure the continuity of the food tradition, family member especially mother should take the initiative to attract young generation to get involved in the cooking activities (Chenhall, 2011). The process of food knowledge transfer occurs spontaneously which usually involved mothers and daughters; it becomes a tradition for most families in all ethnics. However, young generations nowadays decline to get involved and practice their traditional ethnic food. This study attempted to recognize factors restrict young generations to practice Malay traditional festive foods.

\subsection{Literature Review}

\subsection{Malay foods}

Malays are an ethnic group of Austronesia people predominantly inhabiting the Malay Peninsula, including the southernmost parts of Thailand, the east coast of Sumatra, the coast of Borneo, and the smaller islands which lie between these locations. Malay ethnic was believed started from the west side near the east of Africa Continent; the Madagascar Island and emerged to the Southeast Asia (Ishak, 2009). There are varieties of spice in Malay food. The traditional culinary style has been greatly influenced by the long-ago traders from neighbouring countries, such as Indonesia, India, the Middle East, and China. Malay food is often described as spicy and flavourful as it utilizes a melting pot of spices and herbs. Malay traditional food is 
recognized mainly by its geographical location, according to the states. On the west coast, the northern states are well known for their hot, spicy food. This is due to heavy influence of neighbouring Thailand. Malay cooking incorporates ingredients such as lemon grass, pandan (screwpine) leaves, and kaffir lime leaves. Fresh herbs, such as daun kemangi (a type of basil), daun kesum (Polygonum or laksa leaf), nutmeg, kunyit (turmeric) and bunga kantan (wild ginger buds) are often used. Traditional spices such as cumin and coriander are used in conjunction with Indian and Chinese spices such as pepper, cardamom, star anise and fenugreek.

\subsection{Traditional food \& knowledge transmission}

Traditional food refers to foods that have been consumed and practiced locally or regionally for many generations (Pieniak, Verbeke, Vanhonacker, Guerrero, \& Hersleth, 2009). Traditional foods have been influenced by many factors. One of the factors is the availability of raw materials; traditional food is thus influenced by agricultural habits and location (Kuhnlein, Erasmus, \& Spigelski, 2009). On the other hand, traditional foods hold the potential to bind and stabilize communities through continuing their food traditions and practices (Holt \& Amilien, 2007). One of the practical methods to preserve traditional food skills and practices is through food knowledge transmission. Citizens of any age may learn about other traditions and food habits in venues where they can exchange knowledge such as within a community garden or kitchen (Kwik, 2008). Knowledge of traditional foods is necessary for sustaining their development and utilization. It is important for people to know the prevailing traditional food in their areas and how they can be improved for better sustainable their ethnic food traditions (Ohiokpehai, 2003).

\subsection{Methodology}

The study employs the observation method to tap into the actual food preparation process of the Malay festive celebration. The observation processes take place during the 'Hari Raya Aidil Fitri' and 'Hari Raya Aidil Adha' celebrated in August and October 2012. Ten Malay families within Klang Valley Selangor involved in the observed processes. The observation processes supported with the use of a structured fieldwork journal. The observation processes also infuse with picture taking to enable the photographs used as evidence for the study. The observation approach more subjective in nature and involve examining and reflecting on perception to gain an understanding of the social and human activities (Merriam, 2009), that this research dealt with the elders' engagement of perceptions and ideas in the practice of traditional Malay food. The informant selection for this study was split into two generations involved with two generations, mother (age between 50 to 70 years old) and daughter (age between 20 to 40 years old) in a family selected as informants. Malay settlement in Kuala Lumpur is the contextual setting for the study. 


\subsection{Results and Discussions}

\subsection{Lack of exposure \& family support to traditional food knowledge}

Based on the observation (Figure 1) it shows that some family has not practiced or continued the family food tradition for the festive celebration. Therefore, it indirectly influenced the young generation not to practice the traditional foods. Family support is critical in preserving the food tradition. Parents who did not practice and passed down the food knowledge, in the long run, the family food tradition would be left out. At present, this scenario happens because most of the parent's involved in this study especially mother's are working women. Even though they had cooking or food knowledge, they seldom practice or introduce the traditional food to their children due time and working commitment. As a result, the parents end up with eating outside / dining in a restaurant or make a delivery order In the observation it shows that some parent does not be familiar with and never practice the traditional festive foods by their own. They usually depend on their mother or another family member once they gathered at their hometown or kampung. It clearly demonstrates that the parents especially mother do not educate or let their daughter to participate in cooking routine from the early stage (young age). Lack of communication between the older generation and young generation make the situation even worse. Lack of communication between senior and young generation during the activity of food production appear to complicate the situation to transmit or pass down the food knowledge to the young generation.

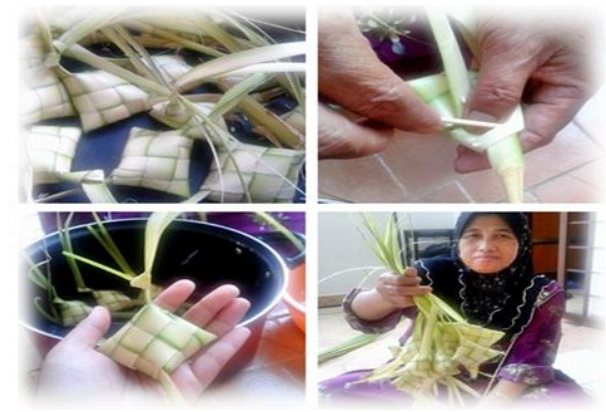

Figure 1: Factors that restrict young generation to practice

Although from the Figure 2 we can see that there is a young generation appeared in the cooking activities they tend to do work separately. As an example can be seen in both families during the production of laksa, when young members are helping with separating fishes' flesh from its bones, the older will work on making laksa noodles. This is because the older generation tends to work on faster pace because of their mission in completing the cooking in time and as the resulting mother usually have no interest to answer questions. So it is 
impossible for the young generation to grasp the pace in doing the dishes because they are still learning stage.

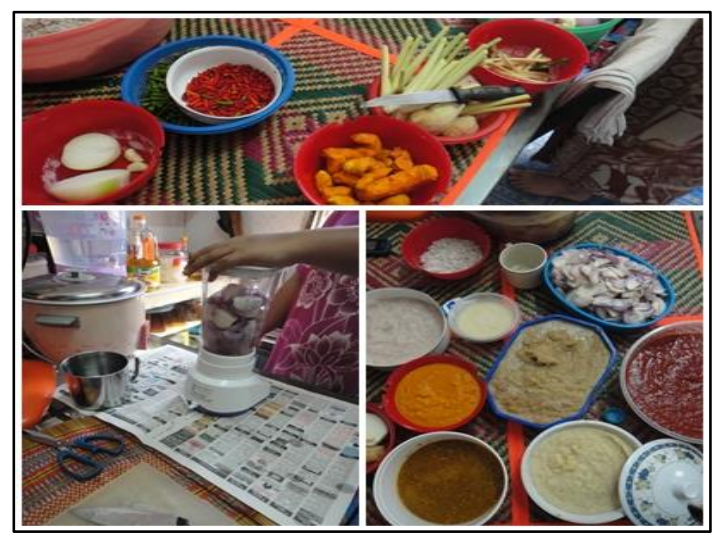

Figure 2: Surrounding influences affected young generation's interest to learn the traditional food knowledge

\subsection{Complicated methods and ingredients}

Another factor that restricts young generation to practice traditional food production is the procedure and steps involved in producing the traditional foods which are tedious and complicated. For instance, in making ketupat (Figure 3 ) is one of the complicated traditional food productions. It involved many steps and procedure.

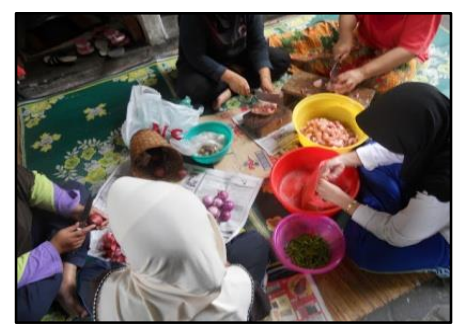

Figure 3: Scenario of the traditional food tradition during festive celebrations

Firstly, it used only young coconut leaves, the leave need to be cleaned and separate it into two pieces before weaving it to be as a ketupat casing. It usually took 5 to 10 minutes to make each ketupat casing. Then the next process is to fill up the ketupat casing with raw rice before 
boil it for several hours (2-4 hours). That does not include other types of food such as rendang, spicy peanut sauce, and lontong gravy. Typically average Malay family spend 6 to 12 hours to prepare and produce Malay traditional foods for the festive celebration. This has made it more complicated and time-consuming. Furthermore, some of the foods are made ready (convenience food) like instant ketupat where it just need to open the packaging and boiled it for one hour which is much easier and faster.

\subsection{Required manpower/more people}

Given the method of cooking and preparing traditional Malay food is complicated, it indirectly makes the process of preparing traditional dishes that require a lot of manpower in the success of the process of preparing traditional delicacies for the festive celebration. It is impossible to prepare this dish for the Malay traditional festive celebration tap it usually involves at least four to eight types of food and it is often cooked in large quantities. This situation has made the younger generation feels the responsibility is so heavy that must be borne or taken when to want to continue the family tradition in providing culinary tradition for the festive celebration

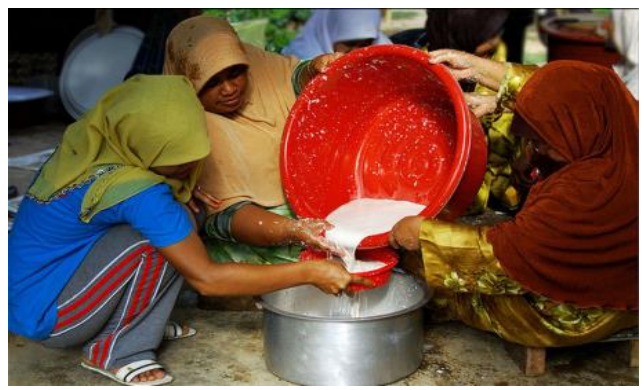

Figure 4: Young generation take parts during food preparation

\subsection{Time consume}

Looking at the process of preparing traditional Malay food to complicate and drag, it has indirectly required the provision of time. Referring to the culture of the Malays always like preparing food in large quantities because of the Malay's like to entertain and give away foods to relatives, neighbours, and friends. Seeing the need of time and length in the preparation of traditional Malay cuisine has made the younger generation indirectly looking at ways to simplify and shorten the period of preparation of this traditional dish. As the results, there are convenience traditional Malay food products in the market. 


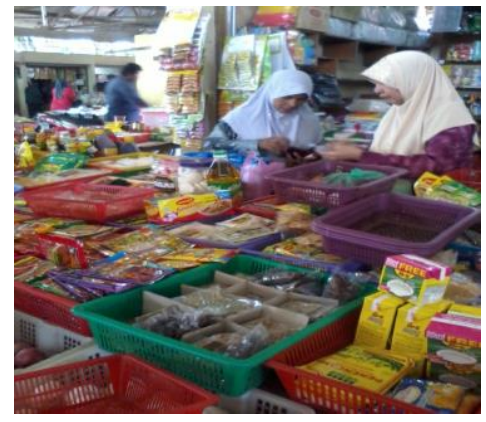

Figure 5: Convenience traditional Malay food products in the market

\subsection{Availability of convenience foods}

The availability of instant food can be obtained from numerous food products that sell at the supermarket. For example, the gravy of rendang is packed in the aluminium package. The consumer just has to heat in and add the main ingredient which is meat or chicken. It is convenient for working mother who does not have enough time to practice in the traditional way. The young generations nowadays prefer to participate in activities that require less commitment and time consume. Their main concern is the fast result and limited cost used.

\subsection{Conclusion}

The most common potential challenges identified related to traditional food knowledge and practice by Malay young generations are involving the parents' role. Parents should have enough knowledge through regular practices of traditional food which can be seen and observed by the children so that it can be followed. Young generations should always be included not only during the preparation, cooking and serving the traditional foods, but they also during purchasing the ingredients (Mohd. Salehuddin et al., 2011; Mohd. Zahari et al., 2011). It is the role of the senior generation to ensure young generation continue practicing traditional foods during festive celebrations (Muhammad, Zahari, Othman, Jamaluddin, \& Rashdi, 2009).

Moreover, this can strengthen the relationship between the family member and build up family spirit without conscious. There is a need to better understand how the Malay young generation in the young age understands messages communicated, the role of traditional food knowledge and parental influence over the Malay traditional festive food knowledge and practices, so that it can either head towards movement to higher stages of sustained behaviour change to family food traditions (traditional food) knowledge and practices (Mohd. Salehuddin et al., 2011; Mohd. Zahari et al., 2011). Therefore, further research pertaining issues in sustaining traditional food knowledge to the young generation is highly encouraged as the issues are rarely explored mainly in the context of Malay Ethnic in Malaysia. 


\section{Acknowledgement}

This research was funded by Ministry of Higher Education, Malaysia through Universiti Teknologi MARA under FRGS grant: 600-RMI/SSP/FRGS 5/3/Fsp (20/2011) and RAGS grant: 600-RMI/RAGS 5/3 (179/2012). This study has been assisted by HS2275 students, academic year 2012/13 from Department of Nutrition \& Dietetics, Faculty of Health Sciences, University Teknologi MARA, Puncak Alam Selangor Malaysia.

\section{References}

Bourdieu, P. (1977). Outline of a theory of practice. New York: Cambridge University Press.

Chenhall, C. (2011). Improving cooking and food preparation skills: a synthesis of the evidence to inform program and policy development (P.-C. P. H. Network, Trans.). Vancover Canada: Public Health Agency of Canada.

Holt, G., \& Amilien, V. (2007). From local food to localised food. Anthropology of food(2).

Ishak, M. A. (2009). Tamadun Alam Melayu (The Malay Civilization). Kuala Lumpur: Persatuan Sejarah Malaysia.

Kuhnlein, H. V., Erasmus, B., \& Spigelski, D. (2009). Indigenous Peoples' food systems: the many dimensions of culture, diversity and environment for nutrition and health. Rome: Food and Agriculture Organization of the United Nations.

Kwik, J. C. (2008). Traditional food knowledge: A case study of an Immigrant Canadian "foodscape". Environments, $36(1), 59-74$

Md. Nor, N., Md. Sharif, M. S., Mohd. Zahari, M. S., Mohd. Salleh, H., Ishak, N., \& Muhammad, R. (2012). The transmission modes of malay traditional food knowledge within generations. procedia - social and behavioral Sciences, 50(0), 79-88. doi: 10.1016/j.sbspro.2012.08.017

Md.Sharif, M. S., Mohd.Zahari, M. S., Noor, N. M., Salleh, H. M., Ishak, N., \& Muhammad, R. (2012). Traditional Food Knowledge (TFK) of Malay festive foods. In Z. e. al (Ed.), Current Issues in Hospitality and Tourism Research and Innovations (pp. 365). London: Taylor \& Francis Group.

Merriam, S. B. (2009). Qualitative research: A guide to design and implementation. San Francisco: Jossey-Bass.

Mohd. Salehuddin, M. Z., Mohd. Syaquif, Y., Mohd. Zain, K., \& Langgat, J. (2011). The level of alteration of ethnic native food: A case of Sarawak, Malaysia. International Journal of Humanities and Social Science, 1(6), 137-145

Mohd. Zahari, M. S., Kamaruddin, M. S. Y., Muhammad, R., \& Kutut, M. Z. (2011). Modernization, Malay matrimonial foodways and the community social bonding. International Journal of Human and Social Sciences, 6(3), 10

Muhammad, R., Zahari, M. S. M., Othman, Z., Jamaluddin, M. R., \& Rashdi, M. O. (2009). Modernization and ethnic festival food Paper presented at the International Conference of Business and Economic, Kuching, Sarawak.

Murphy, C. (2000). Piety and Honor: the Meaning of Muslim Feast in Old Delhi. In S. Khare \& M. Rao (Eds.), Food, Society and Culture: Aspect in South Asian Food Systems. North Carolina: Carolina Academic Press. 
Md. Sharif, M. S., et.al. / Asian Journal Of Quality of Life, AjQoL, Maiden, 1(1), May / June 2016 (p.13-21)

Ohiokpehai, O. (2003). Promoting the nutritional goodness of traditional food products. Pakistan Journal of Nutrition, 2(4), 267-270

Pieniak, Z., Verbeke, W., Vanhonacker, F., Guerrero, L., \& Hersleth, M. (2009). Association between traditional food consumption and motives for food choice in six European countries. [doi: DOI: 10.1016/j.appet.2009.05.019]. Appetite, 53(1), 101-108

UNESCO (2007). Intangible Heritage/2003 Convention, 2011, from

http://www.unesco.org/culture/ich/index.php?lg=en\&pg=00022\#art 